\title{
The Intersection of Preservice Teachers' Confidence, Perceptions, and Ideas for Using Instructional Technology for Teaching and Learning
}

\author{
Louis S. Nadelson ${ }^{1}$, Darcie Bennett ${ }^{1}$, Ezra Gwilliam ${ }^{1}$, Catherine Howlett ${ }^{1}$, Steve Oswalt ${ }^{1} \&$ Jaime Sand $^{1}$ \\ ${ }^{1}$ College of Education, Boise State University, USA \\ Correspondence: Louis S. Nadelson, College of Education, Boise State University, USA. E-mail: \\ louisnadelson@boisestate.edu \\ Received: September 19, 2013 \\ Accepted: October 8, 2013 \\ Online Published: October 9, 2013 \\ doi:10.5430/ijhe.v2n4p77 \\ URL: http://dx.doi.org/10.5430/ijhe.v2n4p77
}

\begin{abstract}
The evolving landscape of instructional technology is influenced by access to a wide range of technology tools that can be accessed to enhance teaching and learning. Technological tools such as smart phones, apps, tablets, social media, and YouTube exemplify the kinds of resources that are readily available for teaching and learning. Further, the development of different course delivery systems and the exposure to concepts such as flipped classrooms and electronic portfolios have extended the use of mainstream technology into new instructional applications. The ongoing evolution of technology hardware, software, and instructional applications has numerous educational implications. In an effort to understand the implications of the evolving landscape of technology in education we examined the responses of 52 preservice teachers to determine their confidence with, perceptions of, and intentions for using instructional technology to teach and learn. Our research revealed a potential misalignment between the participants' comfort, perceptions, and intentions for using technology for teaching and learning. Implications and ideas for further research are discussed.
\end{abstract}

\section{Introduction}

Computers and other forms of electronic technology have become fundamental to society and integral to communication, information seeking and sharing, collaboration, and productivity. These technologies can also be powerful instructional tools, providing ideal learning opportunities for students (Lemke, 2010) while helping them gain insight into the use of technology in the workplace (Bellanca \& Brandt, 2010). However, if used incorrectly, instructional technology may actually hinder productivity by confusing or distracting students in ways that are counterproductive to learning (Schacter, 1999). Thus, it is critical that teachers have the knowledge, comfort, and vision for using instructional technology to create and implement productive learning opportunities for their students (Russell, Bebell, O’Dwyer, \& O’Conner, 2003).

The on-going evolution of technology and the growing array of ways that technology can be used for instruction provide justification for continuing to investigate how preservice teachers envision using technology for enhancing student learning. There is also justification for examining preservice teacher experiences with using technology for learning, as teachers tend to teach as they were taught (Deemer, 2004). If preservice teachers were exposed to learning through technological mediums as K-12 students, they may be more likely to integrate technology into their own teaching. Further, in our search of the literature we were not able to locate any studies that investigated the intersection between preservice teachers' experience and comfort with learning using technology, their preference for teaching with technology, and their visions for how to use technology in instruction. Our research addresses this gap in the literature (Hew \& Brush, 2007) and provides further insight into the influences of preservice teacher technology use within their own teaching and learning environments.

Before we discuss our research methods and results, we lay a foundation for our work discussing technology use for teaching and learning. We also investigate prior studies of educator knowledge and their perceptions surrounding the uses of instructional technology. We then follow our data presentation with a discussion of results and the implications for our research. We provide recognition of our limitations and concluding remarks regarding how our research illuminates the bigger picture of the effective integration of technology for learning and teaching.

\section{Review of Literature}

\subsection{Mandates for Technology in Education - Why Teachers Need to be Prepared}

To begin our discussion of teaching and learning with instructional technology, we offer the following definition of technology: "electronic media such as computers, video, and the associated hardware, networks, and software that enable them to function" (Baek, Jung, \& Kim, 2008, p. 225). Based on this definition we maintain that instructional technology is the application of technology for teaching and learning. The instructional use of technology can 
enhance student learning by creating a context and relevancy that leads to increased motivation, interest, and engagement in course content (Cator, 2013; Project Tomorrow, 2011). Many opportunities created by technology provide learners with ways to be involved with advanced content, creative activities, and authentic assessment, enhancing achievement and academic performance (United States Department of Education, 2010).

Technological enhancements require students to access information and communicate using technology, thus skills must be fostered through the use of technology in education (United States Department of Education, 2010). Furthermore, digital natives, or those students who have grown up immersed in technology, desire and demand this type of technological interfacing as part of the learning experience (Project Tomorrow, 2011). These technological advances translate into states and districts in the United States as striving to include more technology in education. A recent attempt at a systemic approach to addressing instructional technology was the Students Come First initiative in Idaho.

Students Come First was developed to provide equal opportunity and access to education for all students in Idaho, regardless of where they live or their family income. Ensuring that every classroom in every school in Idaho is equipped with the tools of the $21^{\text {st }}$ Century is an important step toward accomplishing this goal. (Idaho State Department of Education, 2011, p. 7)

The goal of the program was ambitious. Within four years the program mandated that every Idaho high school would be wireless and all students and teaching staff would have a laptop device. Elementary schools were also anticipated to benefit from the program by the increased use of $21^{\text {st }}$ century technologies, including interactive white boards, iPods, tablets, and e-Readers, for individualized instruction. (Idaho State Department of Education, 2011)

Idaho is not alone in its quest to implement a statewide laptop program. In 2002 Maine became the first state in the nation to provide laptop computers to all seventh and eighth grade students (Maine Department of Education, 2009). The Maine Department of Education announced the extension of its laptop program to all state high school students by 2009. This extension of its technology initiative was determined to increase student access to information and promote $21^{\text {st }}$ century technology skills by building on the success of the middle school laptop program. The initiative in Maine differed from the Idaho program in that it did not mandate the participation of all school districts in the state.

In addition to a statewide approach, several schools and school districts have begun to offer laptops to students. Warschauer (2006) discussed the implementation of laptop programs by numerous districts in California. He asserted that laptop programs have existed in California since 1996 with districts and schools funding equipment through the use of money from grants, parents, and local school districts. The Portland School District is continuing work toward a laptop initiative where, according to the district's technology plan, all students in grades $6-12$ are to be provided with a portable computer device between 2010 and 2013 (Portland Public Schools, 2009).

As more focused attention is aimed at developing the benefits of technology in the classroom coupled with legislative mandates, it becomes essential to evaluate preservice teachers' experience and comfort with using technology, as well as their perceptions of and preferences for using technology in the classroom. The success of instructional technology initiatives is dependent on the experience, comfort and perceptions of teachers for using technology for teaching and learning.

\subsection{Factors Influencing Teacher Use of Instructional Technology}

There is an interesting paradox with regard to the use of technology for teaching and learning. The crux of the paradox assumes that technology holds promise for increased learning and therefore should be used to enhance student learning, yet teachers may not be prepared or motivated to utilize technology to support instruction and therefore do not seek creative or innovative ways to use technology to enhance student learning (Ertmer \& Ottenbreit-Leftwich, 2010). Complicating the paradox is the range of teachers' perspectives regarding the potential benefit of technology use in the classroom and the complexity surrounding those perspectives (Baek et al, 2008).

Researchers have identified a number of factors that may influence a teacher's likelihood to integrate technology into instruction. Miranda and Russell (2011) reported that the strongest predictors of classroom technology use (in descending order of influence) are 1) a teacher's beliefs about the potential benefits, 2) a teacher's experience with technology, and 3) a teacher's perceived pressure to use technology. Similarly, Baek and colleagues (2008) found a teacher's perceived pressure to use technology proved the strongest motivator in its use in instruction.

Teo (2009) suggested that a teacher's intention to use technology in instruction was directly affected by the perceived usefulness of the technology, attitude towards computer use, and computer self-efficacy. Teo (2009) also found that the teacher's intentionality with technology was indirectly affected by perceptions of the ease and complexity of using the technology in instructional situations. Thus, it is apparent that prior experience and perceptions of the 
usefulness of technology within a learning context play critical roles in teachers' decisions regarding the instructional use of technology.

There is evidence to suggest that while preservice and in-service teachers both recognize the importance of technology use, they need to be prepared to integrate technology in classroom instruction (Lei, 2009; Smarkola, 2008). We argue that within the wide range of factors that may affect the potential use of technology by teachers in classroom settings, consideration surrounding the implementation of technology must acknowledge the preparation, experience with, and perceptions of the teacher.

A strong predictor of teacher reliance on technology use for instruction is her/his experience with technology (Miranda \& Russell, 2011) and we posit that experience may also predict the ways in which teachers use technology in instruction. Teacher experience as students has been documented as influential on a range of teaching variables (Burnett, 2006; Garvis \& Pendergast, 2010; Stuart \& Thurlow, 2000; Wellenreiter, Lucey, \& Hatch, 2010). In discussing the development of pedagogical beliefs and practices of preservice teachers in their education programs, Ertmer and Ottenbreit-Leftwich (2010) noted, "They do not enter the programs with blank slates; their understandings of good teaching are based on their experiences as K-12 students" (p. 271-272). Therefore, it seems likely that teachers' past educational experiences with technology will have a significant influence on how teachers integrate technology into their instruction. Documenting the status of the association between teacher experience with, comfort with, and perceptions of use of instructional technology is justified in the second decade of the $21^{\text {st }}$ century, particularly given the potential for shifts in perceptions as the first generation of digital natives enter the field of education.

\subsection{Instructional Technology Confidence of Preservice Teachers}

As the expectation for technology use in classrooms increases, there is a continuous concern that preservice teachers are adequately prepared and technologically competent (Kim, Jain, Westhoff, \& Rezabek, 2008; Lei, 2009). Wild (1995) reported that $89 \%$ of preservice teachers engaged in some form of technology class, but only $29 \%$ of students felt confident using technology. Though academic activities using technology (on-line courses, research papers, e-projects, etc.) have been a part of preservice teachers' education, it is apparent that these students lack confidence to use technology in a classroom setting (Watson, 1997). Perhaps the lack of confidence can be attributed to inadequate exposure to opportunities to refine teaching with technology during their preparation programs or lack of opportunities to develop confidence for using technology for teaching, particularly with specific subject matter (Baek et al., 2008; Lei, 2009; Stein, Ginns, \& McRobbie, 2003; Sime \& Priestley, 2005). Still, researchers have maintained that post-secondary institutions are appropriate places for preservice teachers to gain the knowledge and confidence for using technology for instruction (Kim et al., 2008). We maintain that with increased educational mandates and increased scrutiny of school effectiveness and performance, teacher confidence with technology is essential for attending to policy goals and assuring students achieve expected learning outcomes, including the development of technological literacy in enhanced learning experiences.

It is likely that preservice teachers who do not feel confident in their use of technology for teaching and learning upon entry into a preservice program are not likely to matriculate with high confidence. In other words, as Birch and colleagues (2008) reported university teacher preparation programs do not necessarily instill technological confidence in preservice teachers. Similarly, Banas (2010) reported, “...teachers believed that technology integration was important, but didn't know how to go about doing it" (p. 124). Thus, teachers may struggle with their capacities and capabilities to effectively use technology in instruction. In addition, many teacher preparation programs may not be adequately responding to this situation with the appropriate coursework and resources to help preservice teacher development in this professional area. Support for teacher development of strategies and techniques for the creative and innovative use of technology is critical particularly given the rapid development and access to a growing array of technologies that could be used for instruction.

The likely association between teachers' confidence with using technology in teaching settings and their experiences with learning technology as students provides justification for assessing confidence in using technology for learning among preservice teachers. Further, the potential for shifts in confidence due to program influences provides a reason for assessing confidence of using technology for learning in a wide range of preservice teachers.

\subsection{Teacher Innovation, Technology, and $21^{\text {st }}$ Century Skills}

Teaching and learning with technology plays a key role in the $21^{\text {st }}$ Century Classroom. According to the Partnership for $21^{\text {st }}$ Century Skills (2007), students need to develop information, media, and technology skills to be competitive in the workplace and have the multi-dimensional abilities required of them in the $21^{\text {st }}$ century. How teachers integrate 
technology into their classrooms is critical in helping students build capacity for life in the $21^{\text {st }}$ century (Casner-Lotto \& Barrington, 2006; Dockstader, 1999). However, conflicting information exists when it comes to how best to prepare teachers to integrate technology (Lambert, Gong, \& Cuper, 2008). Student needs as described in $21^{\text {st }}$ Century Skills coupled with conflicting information about how to prepare teachers to use instructional technology in an effort to foster skill development provides justification for continuing to explore preservice teachers' views of how technology might be used for teaching and learning.

Given the complex variables surrounding teacher confidence such as past experience, pedagogy, training and innovative teaching strategies, simply "knowing" technology is not enough to produce the necessary confidence to engage with it (Otero et al., 2005). Even when teachers know how to utilize technology for personal productivity they often need help understanding how technology can be used to enhance student learning (Dexter, Doering, \& Riedel, 2006). It seems that teachers must be taught to use technology "meaningfully" in their instruction (Otero et al., 2005).

Future teachers must not only be accomplished in instructional techniques and technology, but also in the integration of technology into the curriculum (Dockstader, 1999). Williams, Foulger, and Wetzel (2009) found increased confidence of teachers who are able to incorporate multiple technology integration strategies and who are given the opportunity to practice teaching with technology while deeply understanding the usefulness of the educational technology. In addition to noting the importance of instructional strategies, other factors influencing the successful integration of instructional technology include assurances that the associated learning is meaningful and the integration of technology is consistent with the content-area needs and practices (Dexter, Doering, \& Riedel, 2006; Jaipal \& Figg, 2010). Competent teachers foster meaningful learning when they demonstrate the ability to connect subject matter content and pedagogical processes in ways that promote effective student learning in that content area (Jonassen, Howland, Marra, \& Crismond, 2008).

It is essential to understand personal differences among teachers' attitudes and abilities that could play a role in better understanding which teaching strategies are effective, specifically as related to technology use. The idea of the $21^{\text {st }}$ Century Classroom has not yet been solidly defined, nor have the teacher practices associated with the movement been reified (Williams et al., 2009, p. 396). As Lambert et al. (2008) found,

...course instruction as well as prior technology experience has a significant influence on preservice teachers' ability to understand the usefulness of integrating technology in the classroom, and that student outcomes are strongly related to the use of particular instructional strategies that accommodate widely varying experience levels in learners. (p. 385)

Teachers who keep pace with technology and who are persistently innovative in their instructional strategies have a higher capacity to use technology effectively (Williams et al., 2009).

While definitive classroom practices preparing teachers for the $21^{\text {st }}$ century are not well established, there is a general consensus that it is associated with the effective integration of technology into teaching (Bracewell, Sicilia, Park, \& Tung, 2007; Cuban, Kirkpatrick, \& Peck, 2001; Ertmer, 2005). We argue that determining how to provide teachers with the knowledge and skills needed for their success with instructional technology should be data driven. Thus, enhancing teachers' capacity to effectively use instructional technology begins with assessing their perceptions, experiences, and vision for using technology in the classroom and analyzing the interactions between these variables.

\section{Methods}

The goals of our research were to determine preservice teachers' experience with using instructional technology for learning, their confidence in using the technology for learning, their preferences for using technology for learning and the relationships between these variables. We also sought to determine if there were differences in the experience, confidence, and preferences based on personal characteristics. We used the following research questions to guide our investigation:

1) What are preservice teachers' levels of experience with using different instructional technologies for learning?

2) What are preservice teachers' levels of confidence with using different instructional technologies for learning?

3) What instructional technologies do preservice teachers'foresee they are likely to use in their teaching?

4) What are the relationships between experience, confidence, and likeliness to use various instructional technologies?

5) What learning activities do preservice teachers perceive using instructional technology to accomplish? 
We anticipated that the preservice teachers would have moderate to high prior experience with using technology for learning, because they are likely to have used technology in learning throughout their K-12 and post-secondary careers. However, based on the literature we predicted that their confidence would be lower. We also predicted the participants would indicate preferences for standard forms of technology such as computers. The association between experience, confidence and preference was anticipated to be high, as the literature has shown these to be related. Finally, we anticipated there to be variations in outcomes based on personal characteristics, particularly age and length in the teacher preparation program.

\subsection{Participants}

The participants in our research included students enrolled in preservice teacher preparation programs at universities in the Rocky Mountain West region of the United States. The 52 participants that completed our survey spanned from students entering teacher preparation programs to those in their professional year. The participants ranged in age from 19-54 years of age, with an average of 23.69 years $(S=6.14)$. Over half of the participants indicated that they were preparing to be high school teachers, about $31 \%$ were preparing to be middle school or junior high school teachers, and about $10 \%$ were preparing to be elementary school teachers. Three quarters indicated that they were female, and over $90 \%$ responded that they were Caucasian, with the other $10 \%$ indicating race as Hispanic, Asian, or African American. Half of the participants indicated that they were from suburban environments, with $32 \%$ indicating urban, and $18 \%$ responding they were from rural settings. In Table 1 we report the percentages and count of the participants' responses to their personal use of technology.

Table 1. Technologies Our Participants Regularly Use for Personal Purposes

\begin{tabular}{lll}
\hline Answer Options & Response Percent & Response Count \\
\hline Computer/laptop & $98.1 \%$ & 51 \\
Tablet & $21.2 \%$ & 11 \\
Smartphone & $75.0 \%$ & 39 \\
Social Networking (e.g. Facebook, Twitter, etc.) & $86.5 \%$ & 45 \\
Gaming & $25.0 \%$ & 13 \\
Web 2.0 (blogs, wikis, etc.) & $25.0 \%$ & 13 \\
Podcasts & $7.7 \%$ & 4 \\
\hline
\end{tabular}

\subsection{Instruments}

\subsubsection{Demographics.}

We developed a demographic survey using standard items of age, years of college, level of teaching they were preparing for, and sex. We also included items to determine personal level of technology ownership, such as computers or other similar instructional technology. In addition, we incorporated several items asking participants to characterize their technology skills and experience such as the item asking them to rate their level of comfort using technology on a scale of 1 (very low skilled) to 10 (very high skilled).

3.2.2 Technology experience, confidence, and likeliness to use.

Based on our research goals, we developed our instrument to assess our participants' experience, confidence and preference for using technology for teaching and learning. We elected to conduct our research using a survey due to our desire for a large sample size which would allow us to more effectively determine perceptions, practices, and trends of our participants (Fowler, 2009). Although there are extant instruments to assess confidence (or self-efficacy) for using technology in teaching, the instruments do not align with the experience and preference that we intended to measure. Further, we determined the evolution of instructional technology required the examination of perceptions of hardware, software, and Internet based resources as components of instructional technology.

Once created, we vetted our instrument with faculty teaching in an educational technology department in a College of Education to assure validity of our survey. Based on their feedback we made minor changes to our survey. The changes were to the language of the survey for the purposes of clarification, indicating that our survey was aligned with appropriate content and construct validity.

Our final instrument (available upon request) contained three sections; the first two were identical asking participants to rate the experience and confidence with the technology on a five point Likert like scale. The third section 
requested participants to rate their likeliness to use each form of instructional technology given a specific learning task. All data collected were quantitative, allowing for large-scale data collection.

\subsection{Data collection}

All data collection took place online using Survey Monkey for delivery in Fall 2012. We recruited participants by asking several College of Education faculty at three universities to allow us to invite their students to participate. The invitations, which included a brief overview of our research and a link to our surveys, were distributed by the faculty to the students using their course delivery sites. We allowed two weeks for students to respond and was terminated after we received less than one response per day. Our research was conducted with oversight from our IRB in our Office of Human Subjects.

\section{Results}

\subsection{Experience.}

Our first research question asked, "What are preservice teachers' levels of experience with using different instructional technologies for learning?" To answer this question we analyzed mean responses to our items asking the participants to rate their level of experience with using technology for learning. Our analysis revealed wide variation in the level of experience with different technologies (See Table 2). Technologies scoring above a "4" on the 5-point Likert like scale included email, learning management systems, laptop or desktop computers, television, Internet-based research, online videos, and calculators, which we interpret as indicating near extensive experience. On the other end of the spectrum our participants indicated very limited use of tablets, virtual worlds, podcasts, and gaming, with an average score below " 2 " on the 5-point Likert like scale. The remaining technologies should be considered to be moderate experience with use for learning as they fell between " 2 " and " 4 " on the 5-point Likert like scale.

Table 2. Mean and Standard Deviation of Participants' Experience with Using Different Instructional Technologies

\begin{tabular}{lll}
\hline Answer Options & M & S \\
\hline Virtual worlds & 1.75 & 1.02 \\
Tablet & 1.81 & 1.08 \\
Gaming & 1.9 & 0.95 \\
Podcasts & 1.92 & 1.04 \\
Video conferencing/webinars & 2.08 & 1.16 \\
Simulations & 2.23 & 1.11 \\
Subject-specific software & 2.58 & 1.3 \\
Smartphone & 2.6 & 1.48 \\
Web 2.0 (blogs, wikis) & 2.63 & 1.17 \\
Student response devices (i.e. clickers) & 2.67 & 1.31 \\
Social networking (i.e. Facebook, Twitter) & 2.71 & 1.4 \\
SMART board & 3.17 & 1.37 \\
Spreadsheets & 3.2 & 1.29 \\
Online classes & 3.38 & 1.36 \\
Databases & 3.47 & 1.24 \\
Online videos & 4.02 & 0.99 \\
Television/videos (VHS, DVD, or Blu-ray) & 4.2 & 0.98 \\
Calculator & 4.25 & 1.16 \\
Presentation software & 4.27 & 0.89 \\
Computer/laptop & 4.35 & 0.81 \\
Learning management system (i.e. Blackboard) & 4.39 & 0.86 \\
Word processing & 4.41 & 0.84 \\
Internet research & 4.59 & 0.64 \\
Email & 4.61 & 0.81 \\
\hline
\end{tabular}




\subsection{Confidence.}

Our second research question asked, "What are preservice teachers' levels of confidence with using different instructional technologies for learning?" To answer this question we analyzed the responses to our items asking the participants to rate their level of confidence for using technology for learning (see Table 3). Our analysis reveals consistency with experience in using technology for learning with email, learning management systems, laptop or desktop computers, television, and calculators. We also found high levels of confidence (rated "4" or above) for smartphone, word processing, and social networking. Inconsistent with experience we found moderate levels of confidence for the remaining items.

Table 3. Mean and Standard Deviation of Participants' Confidence for Using Different Instructional Technologies

\begin{tabular}{lll}
\hline Answer Options & M & S \\
\hline Virtual worlds & 2.15 & 1.22 \\
Podcasts & 2.17 & 1.29 \\
Simulations & 2.25 & 1.26 \\
Subject-specific software & 2.77 & 1.15 \\
Video conferencing/webinars & 2.77 & 1.31 \\
Gaming & 2.85 & 1.43 \\
Web 2.0 (blogs, wikis) & 2.98 & 1.25 \\
SMART board & 3.1 & 1.36 \\
Tablet & 3.38 & 1.35 \\
Student response devices (i.e. clickers) & 3.43 & 1.37 \\
Spreadsheets & 3.45 & 1.26 \\
Databases & 3.51 & 1.29 \\
Online classes & 3.69 & 1.25 \\
Online videos & 4.24 & 1.05 \\
Presentation software & 4.25 & 0.96 \\
Social networking (i.e. Facebook, Twitter) & 4.33 & 1.03 \\
Smartphone & 4.35 & 1.18 \\
Learning management system (i.e. Blackboard) & 4.41 & 0.84 \\
Word processing & 4.51 & 0.87 \\
Calculator & 4.55 & 0.58 \\
Internet research & 4.57 & 0.61 \\
Television/videos (VHS, DVD, or Blu-ray) & 4.8 & 0.5 \\
Email & 4.84 & 0.43 \\
Computer/laptop & 4.86 & 0.41 \\
\hline use. & & \\
\hline
\end{tabular}

\subsection{Likeliness to use.}

Our third research question asked, "What instructional technologies do preservice teachers' foresee they are likely to use in their teaching?" To answer this question we analyzed the participants' average responses to our items asking the participants to rate the likeliness that they would use different technologies in their teaching (see Table 4). Our results indicate that the participants are highly likely to use computers/laptops, television videos, email, and internet research in teaching (rated averaged of "4" or above). The participants indicated low likelihood of using gaming, virtual worlds, video conferencing/webinars, podcasts, online classes, smartphones, or social networking for teaching (rated an average of 2.3 or below). We interpret the responses to the remaining items as being moderate likelihood of using the instructional technology for teaching. 
Table 4. Mean and Standard Deviation of Participants' Likeliness to Use Instructional Technologies

\begin{tabular}{lll}
\hline Answer Options & M & S \\
\hline Podcasts & 1.80 & 1.1 \\
Virtual worlds & 1.85 & 1.17 \\
Video conferencing/webinars & 1.88 & 1.07 \\
Gaming & 1.96 & 1.15 \\
Online classes & 2.02 & 1.23 \\
Social networking (i.e. Facebook, Twitter) & 2.16 & 1.42 \\
Smartphone & 2.29 & 1.34 \\
Simulations & 2.35 & 1.34 \\
Student response devices (i.e. clickers) & 2.39 & 1.38 \\
Web 2.0 (blogs, wikis) & 2.41 & 1.26 \\
Tablet & 2.57 & 1.27 \\
Spreadsheets & 2.94 & 1.38 \\
Databases & 3.02 & 1.36 \\
Learning management system (i.e. Blackboard) & 3.08 & 1.38 \\
Subject-specific software & 3.14 & 1.29 \\
Calculator & 3.49 & 1.62 \\
SMART board & 3.63 & 1.42 \\
Presentation software & 3.77 & 1.32 \\
Online videos & 3.92 & 1.11 \\
Word processing & 3.94 & 1.38 \\
Email & 4.04 & 1.27 \\
Internet research & 4.08 & 1.27 \\
Television/videos (VHS, DVD, or Blu-ray) & 4.12 & 1.22 \\
Computer/laptop & 4.47 & 0.96 \\
\hline & & \\
\hline
\end{tabular}

\subsection{Intersection of variables.}

Our fourth research question asked, "What are the relationships between experience, confidence, and likeliness to use various instructional technologies?" We began answering this question by graphing the average of the participants' responses to the items regarding their experience with, confidence with and likelihood to use various instructional technologies (see Figure 1). A review of the ratings reveals some consistencies in ratings of the instructional technologies across contexts such as computer/laptop, television, videos, subject specific software, virtual worlds, and software applications (word processing, databases, etc.). We interpreted the consistency based on the relative alignment of the level of learning experience with, confidence in using, and likelihood to use in teaching with a given technology, regardless of the average levels. Thus, due to the variations in levels between categories we determined it was more meaningful to take a descriptive approach rather than a statistical approach for comparison.

Our analysis also revealed some inconsistencies between the different contexts for instructional technologies such as tablets, smart phones, gaming, social media, video conferencing, and online classes, in which the confidence for using the technology was notably greater than the experience with the technology in learning, and likeliness of use for the technology in their teaching. We interpret these results to suggest that confidence for using an instructional technology may be independent of experience with using the technology for learning or likelihood of using the technology for teaching. 


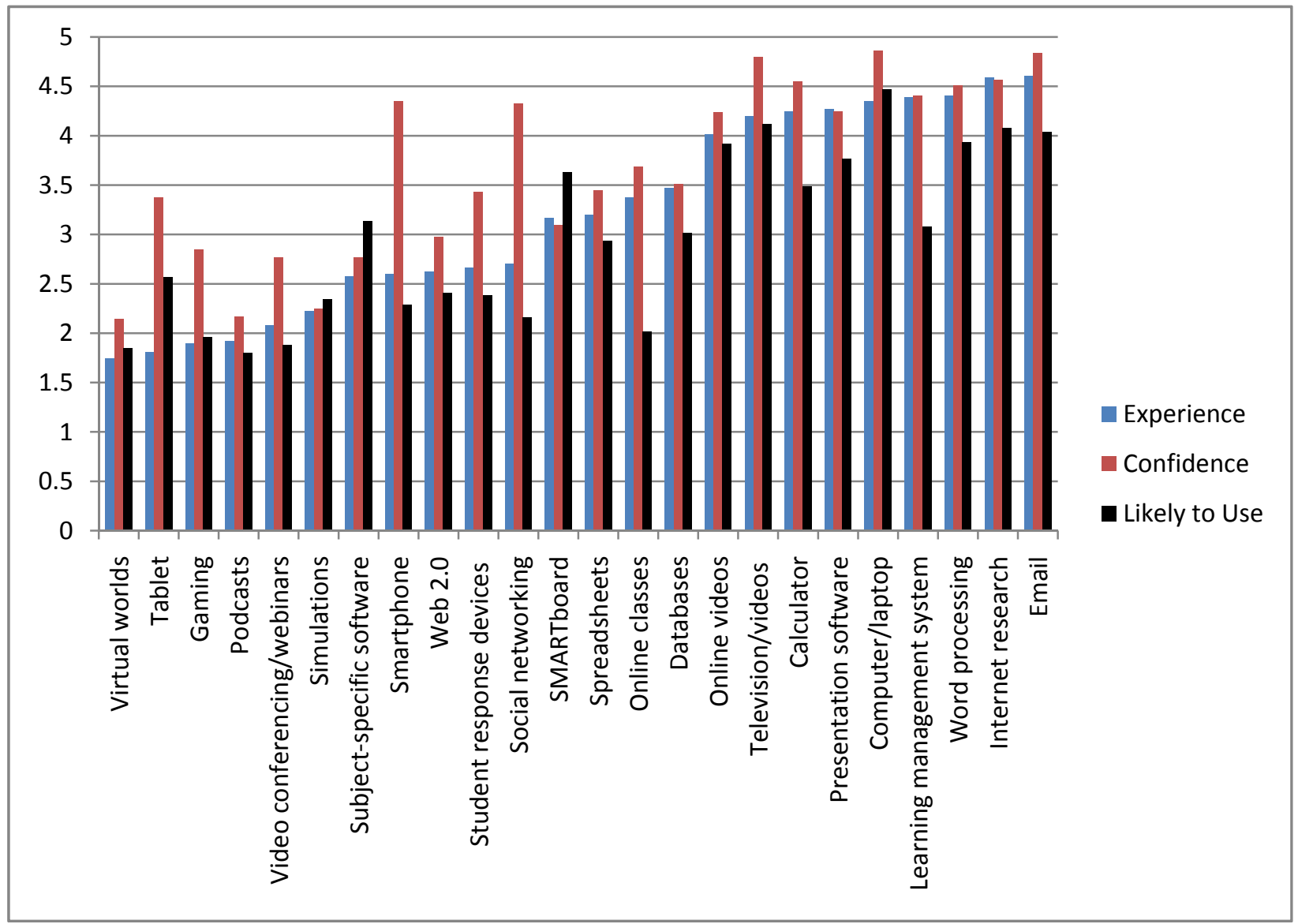

Figure 1. Graphs of the average levels of experience with, confidence for and likeliness to use different instructional technologies

\subsection{Applications of instructional technologies.}

Our final research question asked, "What learning activities do preservice teachers perceive using instructional technology to accomplish?" To answer this question we separated the responses into stand-alone instructional technologies and web-based instructional technologies and graphed the frequency of responses for perceived application of the technology for accomplishing different learning activities (see Figures 2 and 3). Our analysis of the stand-alone instructional technologies revealed the participants perceived potentially using the technologies to accomplish multiple learning goals. Some of the responses were aligned according to the technology such as word processing and writing, and calculators and problem solving, while others were more distal to the standard application of the technology such as peer collaboration and presentation software (see Figure 2). 


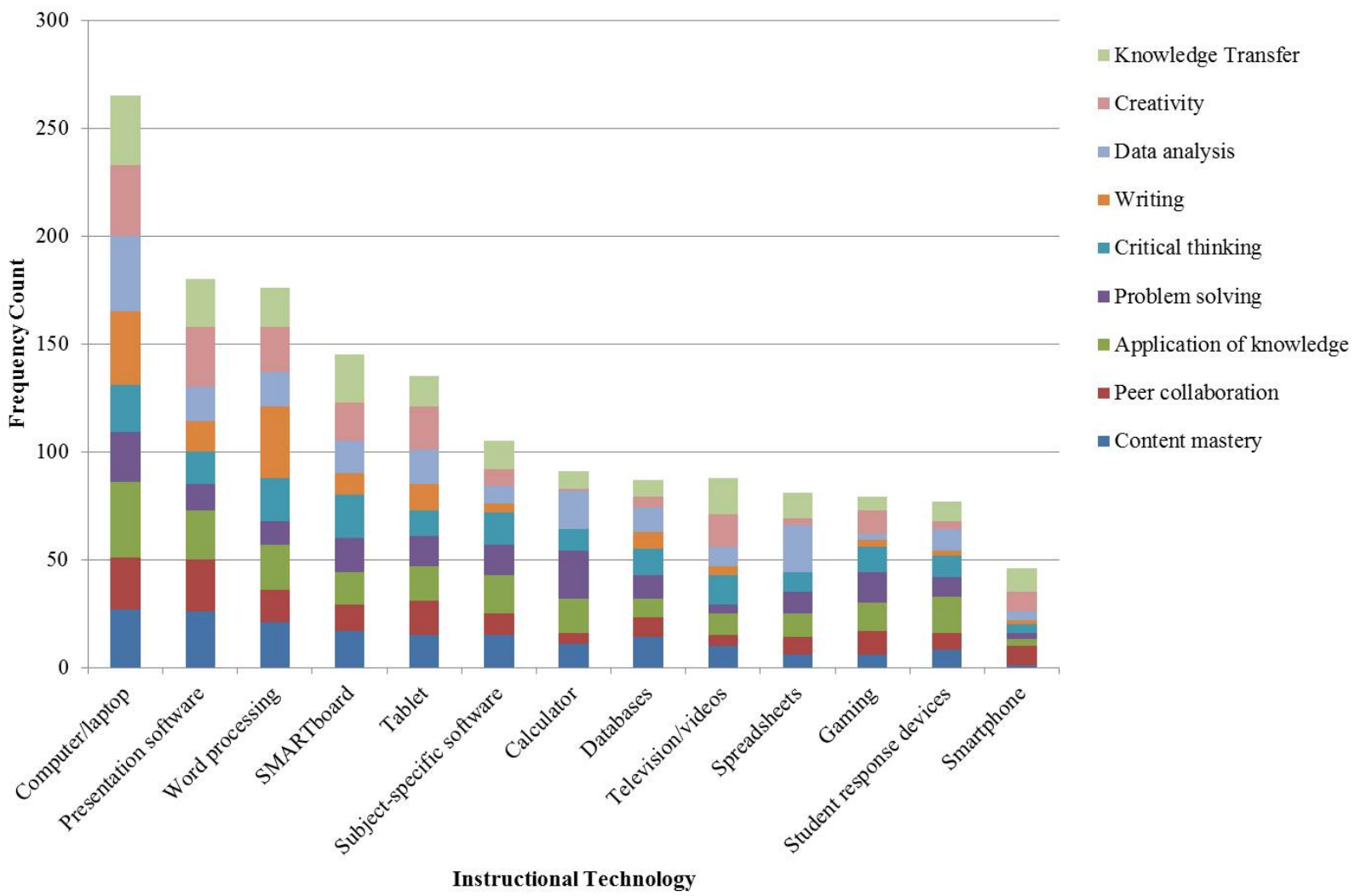

Figure 2. Perceived application of stand-alone instructional technology for accomplishing different learning activities Our analysis of the web-based applications revealed similar results to the stand-alone application, that is, the participants perceive using specific web-based technologies for accomplishing a wide range of learning activities. Peer collaboration did stand out for several of the instructional technologies as having a higher frequency while data analysis was noted at the opposite end, having a low frequency of selection.

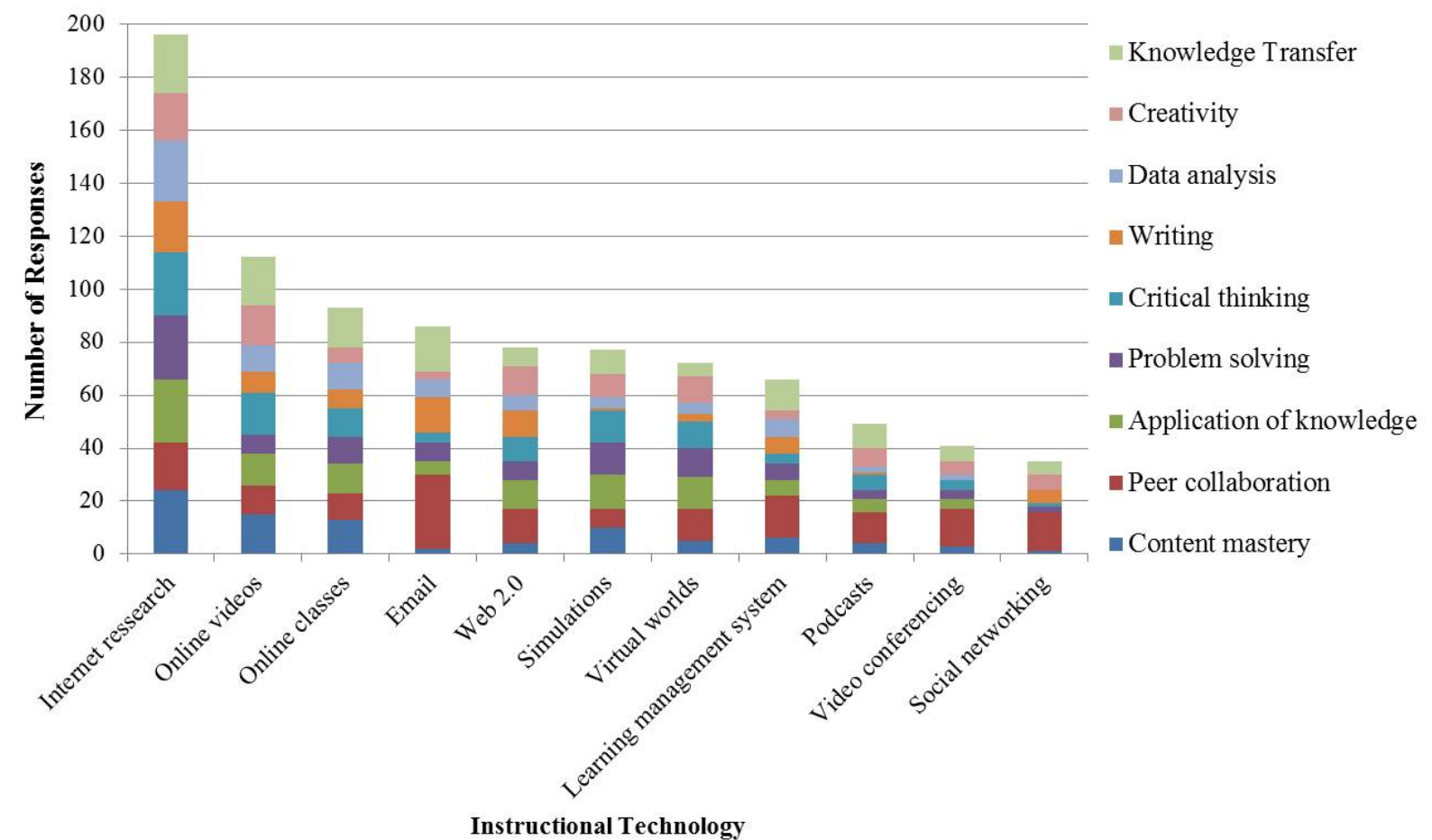

Figure 3. Perceived application of web-based instructional technology for accomplishing different learning activities 


\section{Discussion}

As expectations for student and teacher use of instructional technology increase and access to new technologies evolve, there is a need to monitor various aspects of preservice teachers' personal interactions with and perceptions of instructional technology (Russell et al. 2003). Our project examined preservice teachers' experience using various instructional technologies for learning, their comfort with using the technologies for education, and their likelihood of using the technologies in their teaching.

We found that our participating preservice teachers had varied levels of experience with the different forms of instructional technology. They reported high levels of experience with more common or traditional forms of instructional technology like computers and word processing, but relatively low levels of experience with more recent technologies introduced to instruction such as tablets, gaming, and virtual worlds. The speculate that the explanation for these findings may be found in an examination of the instructional technologies that are most commonly used for teaching and learning and the preparation of the preservice teacher participants to use technology in instruction. Even as gaming, virtual worlds, and tablets are being promoted as potential forms of instructional technology, and have been accessible for several years, it appears that mainstream forms of instructional technology may dominate in teacher preparation; therefore, other forms are not likely explored for instructional use.

We noted a shift in response with respect to our participants' confidence in using various technologies for learning. Most of the instructional technologies for which they had high experience reflected a corresponding high level of confidence. In general confidence seemed to shift to higher levels than was indicated in the participants' indication of experience. We suggest that the explanation for this finding is due to the high probability that students are using a number of technologies for learning outside of their formal education. For example, smartphones have become pervasive in society, but they are not necessarily being utilized in formal instruction even though they may still be used by students to gather and share information. Thus, some of what students learn about the instructional technologies may be taking place outside of the formal learning environment. It may be possible that students have to self-teach many of the processes or functions of a much broader base of instructional technology, which may influence their consideration of new technologies due to the required effort. How students learn to use the instructional technologies they are expected to know for teaching is an excellent direction for further research.

The likelihood of the preservice teachers to use various technologies almost mirrored their experiences with them as learners. Some were slightly higher such as tablets, and some lower, such as social media. The one extreme was online classes. Although experience was high the anticipated use for instruction was notably less. We maintain that experience learning with technology is highly influential on the technologies preservice teachers perceive they will use for instruction. However, the kinds of technologies preservice teachers are expected use in their preparation may not be aligned with the kinds of technologies they would typically use in teaching, as is in the case of course management software.

The intersection between various instructional technologies and the likeliness to use instructional technologies to accomplish different learning objectives again revealed a similar trend. Our data indicate that the participants were likely to select those technologies that they were more experienced with to accomplish a wide range of learning objectives, such as word processing, and presentation software. However, the participants also rated tablets and smart boards as effective technologies for meeting a wide range of learning objectives. Interesting to us was the lack of recognition of smartphones, which are essentially computers, as being effective for meeting a wide range of learning objectives. However, the lack of experience using these devices in formal learning environments may hinder the ability for these preservice teachers to imagine how smartphones might be used to support learning. There may also be a host of classroom management, student access, or equity issues that may be at play.

\subsection{Implications}

The foremost implication for our work is to highlight the apparent lack of alignment between technology comfort and personal use with the expected application of technology for instruction. Smartphones have become pervasive in society and yet our participants rated the likelihood of using the technology for instruction low while they rated their comfort level high. This suggests that if we want teachers to use new technologies for instruction they will likely need to explicitly experience learning and teaching with the technology, which may need to be an integral part of their preparation programs or to ongoing teacher professional development programs. The expectation that teachers will transfer personal use of technology to use of the technology for teaching is perhaps overly optimistic and unrealistic. 
The second implication of our research is the need to provide teachers with a diversity of experiences using technology in learning. The constrained connection between different forms of instructional technologies and the learning activities for which they may be used reflects a need to provide preservice (and perhaps in-service) teachers with a wide range of learning opportunities in which they are using a diversity of technologies to accomplish multiple or perhaps unique learning activities. One example could be to create opportunities that engage preservice teachers in using spreadsheets for communication and problem solving, areas that our participants ranked low in terms of using spreadsheets to accomplish. Again, the use of spreadsheets for problem solving and other misaligned applications of technology for instruction could be addressed in teacher preparation programs.

\subsection{Limitations}

The first limitation of our research is the limited sample size. Although we had a sufficient sample size to draw conclusions and identify trends, the participants were from schools within the same region and schools with similar characteristics, thus limiting generalizability. Perhaps students from different institutions (e.g. large urban universities) would have different perspectives. Conducting this research with a greater diversity of students from a greater diversity of institutions is an excellent direction for future research and may expose differences in technology comfort, perceptions, and experiences.

Our research was self-report and survey research, leaving us to speculate why the participants responded as they did. Building upon our research with interviews or more free response approaches to data collection may provide greater insight into preservice teachers' perceptions and thoughts about using technology for instruction.

\section{Conclusion}

As the landscape of instructional technology continues to evolve it is important that we monitor and report preservice teachers' experience with, comfort with and likelihood to use the wide range (and growing number) of technologies that can be used for instruction. We found some misalignment between preservice teachers' comfort with technology and their experience with and likelihood to use the technology for teaching and learning. Explicit instruction and more experience with a wider range of instructional technologies may be critical to expanding the number and forms of technology teachers consider and use in their instruction. Our research is likely to be useful to those who work with preservice teachers and those who provide professional development to in-service teachers. Responding to the evolution of technology in society and demands to integrate technology for instruction should be data-driven, and our research expanded the empirical foundation upon which related responses may be formed.

\section{References}

Baek, Y., Jung, J., \& Kim, B. (2008). What makes teachers use technology in the classroom? Exploring the factors affecting facilitation of technology with a Korean sample. Computers \& Education, 50(1), 224-234. http://dx.doi.org/10.1016/j.compedu.2006.05.002

Banas, J. R. (2010). Teachers' attitudes toward technology: Considerations for designing preservice and practicing teacher instruction. Community \& Junior College Libraries, 16(2), 114-127. http://dx.doi.org/10.1080/02763911003707552

Bellanca, J., \& Brandt, R. (2010). 21st century skills: Rethinking how students learn. Bloomington, IN: Solution Tree.

Birch, T., Greenfield, L., Janke, K., Schaeffer, D., \& Woods, A. (2008). Partnering with librarians to meet NCATE Standards in teacher education. Education, 28(3), 369-379.

Bracewell, R., Sicilia, C., Park, J., \& Tung, I. (2007, May). Tracking adoption and non-adoption of ICT activities by teachers. Invited presentation to the Technology and Teacher Education Pre-conference, 2007 Congress of the Humanities and Sciences, University of Saskatchewan, Saskatoon.

Burnett, C. (2006). Constructions of professional knowledge among student and practicing primary teachers: Paradigmatic and narrative orientations. Research Papers in Education, 21(3), 315-333. http://dx.doi.org/10.1080/02671520600793773

Casner-Lotto, J., \& Barrington, L. (2006). Are they really ready for work? Report commissioned by The Conference Board, Corporate Voices for Working Families, the Partnership for 21st Century Skills, and the Society for Human Resource [Online] Available: http://www.21stcenturyskills.org/documents/FINAL_REPORT_PDF9-29-06.pdf

Cator, K. (2013). Every day should be digital learning day. Homeroom: The Official Blog of the U.S. Department of 
Education. [Online] Available: http://www.ed.gov/blog/2013/02/every-day-should-be-digital-learning-day/

Cuban, L., Kirkpatrick, H., \& Peck, C. (2001). High access and low use of technologies in high school classrooms: Explaining an apparent paradox. American Educational Research Journal, 38(4), 813-834. http://dx.doi.org/10.3102/00028312038004813

Deemer, S. (2004). Classroom goal orientation in high school classrooms: Revealing links between teacher beliefs and classroom environments. Educational Research, 46(1), 73-90. http://dx.doi.org/10.1080/0013188042000178836

Dexter, S., Doering, A.H., \& Riedel, E. (2006). Content area specific technology integration: A model for educating teachers. Journal of Technology and Teacher Education, 14(2), 325-345.

Dockstader, J. (1999). Teachers of the 21 st century know the what, why, and how of technology integration. $T H E$ Journal, 26(6), 73.

Ertmer, P. A. (2005). Teacher pedagogical beliefs: The final frontier in our quest for technology integration? Educational Technology Research and Development, 53(4), 25-39. http://dx.doi.org/10.1007/BF02504683

Ertmer, P. A., \& Ottenbreit-Leftwich, A. T. (2010). Teacher technology change: How knowledge, confidence, beliefs, and culture intersect. Journal of Research on Technology in Education, 42(3), 255-284.

Fowler, F. J. (Ed.). (2009). Survey research methods (Vol. 1). Thousand, Oaks, CA: Sage.

Garvis, S., \& Pendergast, D. (2010). Middle years teachers' past experiences of the arts: Implications for teacher education. Australian Journal of Music Education, 2, 28-40.

Hew, K., \& Brush, T. (2007). Integrating technology into K-12 teaching and learning: Current knowledge gaps and recommendations for future research. Educational Technology Research and Development, 55(3), 223-252. http://dx.doi.org/10.1007/s11423-006-9022-5

Idaho State Department of Education. (2011). Students come first. [Online] Available: www.sde.idaho.gov/.../Students\%20First\%20White\%20Paper\%20FINAL, \%20updated\%20April\%2022,\%2020 11.pdf

Jaipal, K., \& Figg, C. (2010). Unpacking the total PACKage: Emergent TPACK characteristics from a study of preservice teachers teaching with technology. Journal of Technology and Teacher Education, 18(3), 415-441.

Jonassen, D., Howland, J., Marra, R. M., \& Crismond, D. (2008). How does technology facilitate learning? Meaningful Learning With Technology (5-10). NJ: Pearson Allyn Bacon Prentice Hall.

Kim, K., Jain, S., Westhoff, G., \& Rezabek, L. (2008). A quantitative exploration of preservice teachers ' intent to use computer-based technology. Journal of Instructional Psychology, 35(3), 275-288.

Lambert, J., Gong, Y., \& Cuper, P. (2008). Technology, transfer and teaching: The impact of a single technology course on preservice teachers' computer attitudes and ability. Journal of Technology and Teacher Education, $16(4), 385-410$.

Lei, J. (2009). Digital natives as preservice teachers: What technology preparation is needed? Journal of Computing in Teacher Education, 25(3), 87-97.

Lemke, C. (2010). Innovation through technology. In J. Bellanca and R. Brandt (Eds.), 21st century skills: Rethinking how students learn (243-272). Bloomington, IN: Solution Tree Press.

Maine Department of Education. (2009). Maine expands laptops to high school students. [Online] Available: http://mainedoenews.net/2009/03/11/maine-expands-laptops-to-high-school-students/

Miranda, H., \& Russell, M. (2011). Predictors of teacher-directed student use of technology in elementary classrooms: A multilevel SEM approach using data from the USEIT study. Journal of Research on Technology in Education, 43(4), 301-323.

Otero, V., Peressini, D., Meymaris, K., Ford, P., Garvin, T., Harlow, D., Reidel, M., \& Mears, C. (2005). Integrating technology into teacher education: A critical framework for implementing reform. Journal of Teacher Education, 56(1), 8-23. http://dx.doi.org/10.1177/0022487104272055

Partnership for 21 st Century Skills. (2007). Statement of principles: Twenty-first century skills and the reauthorization of $N C L B / E S E A$. [Online] Available: http://www.p3.org

Portland Public Schools. (2009). Learning technology plan learning technology plan: July 1, 2010 - June 30, 2013. 
[Online] Available: http://www2.portlandschools.org/sites/default/files/PPSTechPlan2010-13_2.pdf

Project Tomorrow. (2011). The new 3 E's of education: enabled, engaged, empowered. [Online] Available: http://www.tomorrow.org/speakup/pdfs/SU10_3EofEducation_Educators.pdf

Russell, M., Bebell, D., O'Dwyer, L., \& O'Connor, K. (2003). Examining teacher technology use: Implications for preservice and inservice teacher preparation. Journal of Teacher Education, 54(4), 297-310. http://dx.doi.org/10.1177/0022487103255985

Schacter, J. (1999). The impact of education technology on student achievement: What the most current research has to say. Santa Monica, CA: Milken Exchange on Education Technology. [Online] Available: www.mff .org/pubterms.taf?fi le=http://www.mff .org/pubs/ME161.pdf

Sime, D., \& Priestley, M. (2005). Student teachers ' first reflections on information and communications technology and classroom learning: implications for initial teacher education. Journal of Computer Assisted Learning, 21(2), 130-142. http://dx.doi.org/10.1111/j.1365-2729.2005.00120.x

Smarkola, C. (2008). Efficacy of a planned behavior model: Beliefs that contribute to computer usage intentions of student teachers and experienced teachers. Computers in Human Behavior, 24(3), 1196-1215. http://dx.doi.org/10.1016/j.chb.2007.04.005

Stein, S. J., Ginns, I. S., \& McRobbie, C. J. (2003). Grappling with teaching design and technology: a beginning teacher's experiences. Research in Science \& Technological Education, 21(2), 141-157. http://dx.doi.org/10.1080/0263514032000127202

Stuart, C., \& Thurlow, D. (2000). Making it their own: Preservice teachers' experiences, beliefs, and classroom practices. Journal of Teacher Education, 51(2), 113-121. http://dx.doi.org/10.1177/002248710005100205

Teo, T. (2009). Modeling technology acceptance in education: A study of pre-service teachers. Computers \& Education, 52(2), 302-312. http://dx.doi.org/10.1016/j.compedu.2008.08.006

Warschauer, M. (2006). Laptops and literacy: Learning in the wireless classroom. New York: Teachers College Press.

United States Department of Education. (2010). Transforming American education learning Powered by technology national education technology plan. [Online] Available: http://www.ed.gov/edblogs/technology/netp-2010/

Watson, G. (1997). Pre-service teachers ' views on their information technology education. Journal of Information Technology for Teacher Education, 6(3), 255-270. http://dx.doi.org/10.1080/14759399700200021

Wellenreiter, B. R., Lucey, T. A., \& Hatch, D. D. (2010). Looking back at their futures: Preservice middle level teachers' examination of past educational experiences. RMLE Online: Research In Middle Level Education, 34(1), 1-11.

Wild, M. (1995). Pre-service teacher education programs for information technology: An effective education? Journal of Information Technology for Teacher Education, 4(1), 7-20. http://dx.doi.org/10.1080/0962029950040102

Williams, M. K., Foulger, T. S., \& Wetzel, K. (2009). Preparing preservice teachers for 21st Century classrooms: Transforming attitudes and behaviors about innovative technology. Journal of Technology and Teacher Education, 17(3), 393-418. 